\title{
Persistently high venous-to-arterial carbon dioxide differences during early resuscitation are associated with poor outcomes in septic shock
}

\author{
Gustavo A Ospina-Tascón ${ }^{1}{ }^{2}$, Diego F Bautista-Rincón ${ }^{1}$, Mauricio Umaña ${ }^{1}$, José D Tafur ${ }^{1}$, Alejandro Gutiérrez ${ }^{1}$,
} Alberto F García', William Bermúdez², Marcela Granados ${ }^{1}$, César Arango-Dávila² and Glenn Hernández ${ }^{3}$

\begin{abstract}
Introduction: Venous-to-arterial carbon dioxide difference $\left(\mathrm{Pv}-\mathrm{aCO}_{2}\right)$ may reflect the adequacy of blood flow during shock states. We sought to test whether the development of $\mathrm{Pv}_{-} \mathrm{aCO}_{2}$ during the very early phases of resuscitation is related to multi-organ dysfunction and outcomes in a population of septic shock patients resuscitated targeting the usual oxygen-derived and hemodynamic parameters.

Methods: We conducted a prospective observational study in a 60-bed mixed ICU in a University affiliated Hospital. 85 patients with a new septic shock episode were included. A Pv-aCO2 value $\geq 6 \mathrm{mmHg}$ was considered to be high. Patients were classified in four predefined groups according to the $\mathrm{Pv}$-aCO2 evolution during the first 6 hours of resuscitation: (1) persistently high Pv-aCO2 (high at T0 and T6); (2) increasing Pv-aCO2 (normal at T0, high at T6); (3) decreasing Pv-aCO2 (high at T0, normal at T6); and (4) persistently normal Pv-aCO2 (normal at T0 and T6). Multiorgan dysfunction at day-3 was compared for predefined groups and a Kaplan Meier curve was constructed to show the survival probabilities at day-28 using a log-rank test to evaluate differences between groups. A Spearman-Rho was used to test the agreement between cardiac output and Pv-aCO2. Finally, we calculated the mortality risk ratios at day-28 among patients attaining normal oxygen parameters but with a concomitantly increased Pv-aCO2.
\end{abstract}

Results: Patients with persistently high and increasing $\mathrm{PV}-\mathrm{aCO}_{2}$ at $\mathrm{T} 6$ had significant higher SOFA scores at day-3 $(p<0.001)$ and higher mortality rates at day-28 (log rank test: 19.21, $p<0.001)$ compared with patients who evolved with normal $\mathrm{Pv}-\mathrm{aCO}$ at T6. Interestingly, a poor agreement between cardiac output and $\mathrm{Pv}-\mathrm{aCO} 2$ was observed $\left(\mathrm{r}^{2}=0.025\right.$, $\mathrm{p}<0.01)$ at different points of resuscitation. Patients who reached a central venous saturation $(\mathrm{ScvO})_{2} \geq 70 \%$ or mixed venous oxygen saturation $\left(\mathrm{SvO}_{2}\right) \geq 65 \%$ but with concomitantly high $\mathrm{Pv}-\mathrm{aCO}$ at different developmental points (i.e., T0, T6 and T12) had a significant mortality risk ratio at day-28.

Conclusion: The persistence of high $\mathrm{Pv}_{-} \mathrm{aCO}$ 2 during the early resuscitation of septic shock was associated with more severe multi-organ dysfunction and worse outcomes at day-28. Although mechanisms conducting to increase $\mathrm{Pv}$-aCO2 during septic shock are insufficiently understood, $\mathrm{Pv}-\mathrm{aCO}_{2}$ could identify a high risk of death in apparently resuscitated patients.

\footnotetext{
* Correspondence: gusospin@gmail.com

${ }^{1}$ Intensive Care Unit, Fundación Valle del Lili, Av. Simón Bolívar Cra. 98, Cali,

Colombia

2Biomedica Research Group, Universidad ICESI, Cali, Colombia

Full list of author information is available at the end of the article
} 


\section{Introduction}

Inadequate tissue perfusion is a pivotal factor in the pathogenesis and clinical course of multiorgan failure in the critically ill [1]. Current techniques for monitoring tissue perfusion have largely focused on systemic blood flow and the balance between oxygen demand and supply $[2,3]$. An early hemodynamic optimization that targets central venous oxygen saturation $\left(\mathrm{ScvO}_{2}\right)$ and systemic hemodynamic parameters improves outcomes in severe sepsis and septic shock [4], reinforcing the idea that tissue perfusion abnormalities are flow dependent at least during the very early stages. However, normalizing systemic hemodynamic parameters does not guarantee adequate tissue perfusion [5-7], and in fact a substantial number of patients still progress to multiorgan dysfunction and death despite meeting $\mathrm{ScrO}_{2}$ targets [4].

In the past, authors described the coexistence of venous acidemia and increased venous carbon dioxide $\left(\mathrm{CO}_{2}\right)$ during cardiac arrest in both animals [8] and critically ill humans [9]. Thereafter, increases in the venous-to-arterial carbon dioxide difference $\left.(\mathrm{Pv}-\mathrm{aCO})_{2}\right)$ were reported during hypovolemic, cardiogenic, obstructive, and septic shock [10-12]. Interestingly, an inverse curvilinear relationship between $\mathrm{Pv}-\mathrm{aCO}_{2}$ and cardiac output was described, highlighting the importance of blood flow on venous $\mathrm{CO}_{2}$ accumulation $[13,14] . \mathrm{Pv}^{-} \mathrm{aCO}_{2}$ thus aroused clinical interest as a marker of global perfusion during shock states, although some studies questioned its prognostic value [14]. In fact, some in vivo models evaluating the mechanisms conducting to venous $\mathrm{CO}_{2}$ accumulation during noninflammatory conditions [15-17] challenged the ability of $\mathrm{Pv}-\mathrm{aCO}{ }_{2}$ to identify tissue dysoxia because it only rises during ischemic hypoxia, but not during hypoxic or anemic hypoxia for comparable declines in oxygen delivery and oxygen consumption. However, more recent data suggest that high $\mathrm{Pv}-\mathrm{aCO} \mathrm{CO}_{2}$ could identify septic patients who remain inadequately resuscitated despite achieving oxygen metabolism targets, reinforcing the notion of Pv$\mathrm{aCO}_{2}$ as a marker of global perfusion due to its ability to track blood flow alterations [18] or even detect anaerobic $\mathrm{CO}_{2}$ generation [19]. Furthermore, patterns of recovery or derangement of $\mathrm{Pv}-\mathrm{aCO}$ during very early stages of resuscitation of septic shock have not been widely described and recent studies trying to demonstrate the reliability of $\mathrm{Pv}-\mathrm{aCO}_{2}$ as a tool in resuscitation of septic patients could have been influenced by selection bias because not all potential patients were elected to catheter insertion and goal-directed therapy $[20,21]$.

Recent publications in critical care demonstrate that oxygen-derived parameters such as $\mathrm{ScvO}_{2}$ or mixed venous oxygen saturation $\left(\mathrm{SvO}_{2}\right)$ are commonly normalized at ICU admission [22] and maneuvers such as emergent intubation can quickly improve $\mathrm{ScvO}_{2}$ despite regional and tissue perfusion derangements [23]. Because global and regional hypoperfusion have been incriminated in the development of multiple organ failure, investigation on surrogate markers of such phenomenon remains important in critical care. Given that $\mathrm{Pv}-\mathrm{aCO}{ }_{2}$ can track the adequacy of systemic perfusion during shock states, we sought to test whether the time course of $\mathrm{Pv}-\mathrm{aCO}$ during the early phases of resuscitation is related to the development of more severe multiorgan dysfunction and worse outcomes in a population of septic shock patients resuscitated by targeting the usual oxygen-derived and hemodynamic parameters.

\section{Materials and methods}

This prospective observational study was performed in a 60-bed mixed ICU in a university-affiliated hospital. We examined all patients with a new septic shock episode admitted to the emergency room or proceeding from clinical wards during a 24-month period. Septic shock was defined using the criteria of the American College of Chest Physicians and the Society of Critical Care Medicine Consensus Conference [24]. Patients were excluded if they were younger than 18 years old, pregnant, had severe chronic obstructive pulmonary disease (GOLD 3 and 4 categories according to the current classification at the time of our study) or advanced liver cirrhosis (Child-Pugh C).

\section{General management}

All patients admitted to the emergency room or proceeding from clinical wards who fulfilled the diagnosis criteria for septic shock were evaluated by the ICU rapid response team according to our local procedures. Each patient was equipped with an arterial cannula and a pulmonary artery catheter (CCO Swan-Ganz catheter; Edwards Life sciences, Irvine, CA, USA). Our early goal-directed therapy included a bundle of interventions that sought to obtain: mean arterial pressure $\geq 65 \mathrm{mmHg}$; urine output $\geq 0.5 \mathrm{ml} / \mathrm{kg} /$ minute; normalization of serum lactate; and $\mathrm{ScvO}_{2} \geq 70 \%$ or $\mathrm{SvO}_{2} \geq 65 \%$. The use of vasopressors (dopamine or norepinephrine) was standardized to maintain a mean arterial pressure $\geq 65 \mathrm{mmHg}$, and repeated fluid challenges with crystalloids or colloids were used to optimize the stroke volume as well as to allow the lowest dose of vasopressors and pulse-pressure variability $<12 \%$. Dobutamine was added for persistent $\mathrm{ScvO}_{2} \leq 70 \%$ or $\mathrm{SvO}_{2} \leq 65 \%$ after fluid resuscitation. A low dose of hydrocortisone was given within 6 hours of resuscitation when use of vasopressors persisted after an adequate fluid restitution. Mechanical ventilation was provided when needed under light sedation (midazolam) and analgesia (fentanyl); the tidal volume was limited to 6 to $8 \mathrm{ml} / \mathrm{kg}$. Glycemic control was adjusted to maintain glucose levels $<150 \mathrm{mg} / \mathrm{dl}$. Finally, stress ulcer and venous thrombosis prophylaxis were provided according to international recommendations [25]. 


\section{Study protocol}

The Fundación Valle del Lili's Ethical and Biomedical research committee approved the current study. A written informed consent was waived because no new therapeutic interventions were performed and all measurements and procedures routinely followed the local protocols for the management of severe sepsis and septic shock.

Time 0 (T0) was declared when the pulmonary artery catheter was inserted using common monitoring tracings to place the distal port in the pulmonary artery and the proximal port in the right atrium, approximately 3 $\mathrm{cm}$ above the tricuspid valve. In order to standardize T0, we recorded the total volume of fluids administered and the time elapsed between the start of resuscitation (first hypotension episode) and the pulmonary artery catheter insertion (T0).

We collected arterial venous blood samples and central and mixed venous blood samples for arterial-venous gases (ABL 300; Radiometer Copenhagen, Denmark) and arterial lactate measurements at T0, and 6 hours (T6), 12 hours (T12) and 24 hours (T24) later. We simultaneously registered hemodynamic and respiratory variables at each measurement. We defined $\mathrm{Pv}-\mathrm{aCO}_{2}$ as the difference between the mixed venous $\mathrm{CO}_{2}$ partial pressure and the arterial $\mathrm{CO}_{2}$ partial pressure. Previous studies considered $\mathrm{Pv}-\mathrm{aCO}_{2} \geq 6 \mathrm{mmHg}$ abnormal [14]. Hence, we classified the patients according to the $\mathrm{Pva}-\mathrm{CO}_{2}$ development during the first 6 hours of resuscitation: persistently high $\mathrm{Pv}_{-} \mathrm{aCO}_{2}$ (high at $\mathrm{T} 0$ and T6); increasing $\mathrm{Pv}^{-\mathrm{aCO}_{2}}$ (normal at T0, high at T6); decreasing $\mathrm{Pv}-\mathrm{aCO}_{2}$ (high at $\mathrm{T0}$, normal at T6); and persistently normal $\mathrm{Pv}-\mathrm{aCO} 2$ (normal at T0 and T6). The Sequential Organ Failure Assessment score [26] was used to describe multiorgan dysfunction at day 3 and we also described mortality at day 28 for the pre-defined groups.

\section{Data analysis}

After exclusion of a normal distribution of the data by the Kolmogorov-Smirnov test, we used a Kruskal-Wallis test to compare continuous variables (followed by Bonferroni correction for multiple comparisons) and a chi-squared test (or Fisher's exact test, when appropriate) for discrete variables. Survival probabilities at day 28 were described using a Kaplan-Meier curve and differences between groups were calculated using a log-rank test before and after adjusting for $\mathrm{SvO}_{2}$ at T6. The development of $\mathrm{SvO}_{2}, \mathrm{ScvO}_{2}$, lactate, cardiac output, mean arterial pressure and $\mathrm{Pv}-\mathrm{aCO}_{2}$ during the first 24 hours were analyzed using a repeated-measures analysis of variance. Spearman's rho was used to test the agreement between cardiac output and $\mathrm{Pv}-\mathrm{aCO}_{2}$. We also calculated the mortality risk ratios at day 28 in patients who attained $\mathrm{ScvO}_{2} \geq 70 \%$ or $\mathrm{SvO}_{2} \geq 65 \%$ but maintained persistently high $\mathrm{Pv}-\mathrm{aCO}{ }_{2}$ at different points during resuscitation (T0, T6, and T12). Data were expressed as medians and 25 to $75 \%$ interquartile ranges. $P \leq 0.05$ (twotailed) was considered significant.

\section{Results}

During the 24-month period, 108 patients older than 18 years with a new episode of septic shock were screened. Patients with advanced cirrhosis $(n=4)$, patients with severe chronic obstructive pulmonary disease $(n=8)$ and pregnant women $(n=4)$ were not included for analysis; additionally, a central catheter could not be placed in four patients, and three refused the procedure. The final sample was therefore 85 patients. The median length of ICU stay for all patients was 6 days ( 25 to $75 \%$ interquartile range, 3 to 11 days), and the 28 -day mortality rate was $37.6 \%$. The median time elapsed from sepsis-induced hypotension to catheter insertion was 3.0 hours ( 25 to $75 \%$ interquartile range, 1.0 to 4.0 hours) and the median volume of fluids received before catheter insertion was $2,079 \mathrm{ml}(25$ to $75 \%$ interquartile range, 1,184 to $3,135 \mathrm{ml}$ ) for all patients.

Thirty-six patients had $\mathrm{Pv}_{-} \mathrm{aCO} \mathrm{CO}_{2}<6.0 \mathrm{mmHg}$ at $\mathrm{TO}$ and T6, and 17 patients had a high $\mathrm{PvaCO}_{2}$ at T0 but it fell below $6 \mathrm{mmHg}$ at T6 (a total of 53 patients had $\mathrm{Pv}-\mathrm{aCO}_{2}<6 \mathrm{mmHg}$ at $\mathrm{T} 6$ ); on the other hand, 24 patients had a persistently high $\mathrm{Pv}_{\mathrm{v}} \mathrm{aCO} \mathrm{CO}_{2}$ during the first 6 hours and the remaining eight evolved from normal at T0 to high $\mathrm{PvaCO}_{2}$ at T6 (32 patients had $\mathrm{Pv}-\mathrm{aCO} \mathrm{C}_{2} \geq 6 \mathrm{mmHg}$ at $\mathrm{T} 6$ ).

We did not find any significant difference with regard to Acute Physiology and Chronic Health Evaluation II score, comorbidities, demographics, or respiratory and hemodynamic variables between groups (Tables 1 and 2), and neither for the volume of fluids received before inclusion (T0). Doses of vasopressors or inotropic received were similar for the groups both at T0 and T6 (Table 2). Multiorgan dysfunction at day 3 was significantly higher among patients with persistently high $\mathrm{Pv}-\mathrm{aCO}_{2}$ compared with those with persistently normal or decreasing $\mathrm{Pv}-\mathrm{aCO}_{2}$ during the first 6 hours of resuscitation (Kruskal-Wallis test, $P<0.001$ ) (Figure 1). Likewise, patients with persistently high $\mathrm{Pv}-\mathrm{aCO}_{2}$ during the first 6 hours of resuscitation had a significant lower survival at day 28 compared with those who normalized Pv$\mathrm{aCO}_{2}$ during this period (log-rank, Mantel-Cox: 19.21, $P<0.001$; Figure 2). These results were maintained after adjusting for the $\mathrm{SvO}_{2}$ achieved at T6 (log-rank test, $P<0.001)$. The time course of $\mathrm{SvO}_{2}, \mathrm{ScvO}_{2}$ and cardiac output did not significantly differ between $\mathrm{Pv}_{\mathrm{v}} \mathrm{aCO}{ }_{2}$ groups (Table 2) nor between survivors and nonsurvivors at day 28 (Figures S1a,b and S2 in Additional file 1). Interestingly, a poor agreement between cardiac output and $\mathrm{Pv}-\mathrm{aCO}$ was observed both at each time of resuscitation and when all data were pooled $\left(r^{2}=0.025, P<0.01\right)$ (Figure 3; Figure S3 in Additional file 1). 
Table 1 Patient characteristics

\begin{tabular}{|c|c|c|c|c|c|}
\hline Variable & $\begin{array}{l}\text { Group 1, H-H } \\
(n=24)\end{array}$ & $\begin{array}{l}\text { Group 2, L-H } \\
(n=8)\end{array}$ & $\begin{array}{l}\text { Group 3, H-L } \\
(n=17)\end{array}$ & $\begin{array}{l}\text { Group 4, L-L } \\
(n=36)\end{array}$ & $P$ value \\
\hline Age (years) & $63.0(54.7$ to 75.0$)$ & $63.5(50.5$ to 76.5$)$ & $55.0(53.0$ to 76.0$)$ & $62.0(49.3$ to 71.8$)$ & 0.83 \\
\hline Gender, male (\%) & $17(70.8)$ & $4(50.0)$ & $10(58.8)$ & $22(61.1)$ & 0.72 \\
\hline APACHE ॥ & 24.4 (21.2 to 26.0$)$ & $25.2(21.0$ to 27.0$)$ & 23.4 (21.2 to 25.6$)$ & $24.8(22.2$ to 25.8$)$ & 0.11 \\
\hline $\begin{array}{l}\text { Time between diagnosis and catheter } \\
\text { insertion (TO) }\end{array}$ & $2.0(2.0$ to 4.0$)$ & $1.0(1.0$ to 3.3$)$ & $3.0(1.0$ to 4.0$)$ & $3.0(2.0$ to 4.0$)$ & 0.44 \\
\hline Fluids received before catheter insertion & $2,039(1,343$ to 2,834$)$ & $1,934$ (849 to 4,575$)$ & $2,500(1,430$ to 3,628$)$ & $2,000(1,025$ to 3,153$)$ & 0.76 \\
\hline Temperature $\left({ }^{\circ} \mathrm{C}\right)$ & 37.5 (37.2 to 37.9$)$ & 37.4 (37.1 to 37.9$)$ & $37.6(37.0$ to 38.0$)$ & 37.4 (37.4 to 37.8$)$ & 0.74 \\
\hline Hemoglobin (g/dl) & 9.4 (8.7 to 11.6$)$ & $8.8(7.4$ to 11.4$)$ & 9.8 (9.1 to 11.4$)$ & $9.9(9.1$ to 11.4$)$ & 0.47 \\
\hline \multicolumn{6}{|l|}{ Source of infection, $n(\%)$} \\
\hline Pneumonia & 9 & 3 & 4 & 10 & \\
\hline Abdominal & 8 & 4 & 6 & 14 & \\
\hline Urinary & 2 & 1 & 3 & 4 & \\
\hline Soft tissue & 2 & 0 & 1 & 2 & \\
\hline No specific site & 3 & 0 & 2 & 4 & \\
\hline Other & 0 & 0 & 1 & 2 & \\
\hline Culture positive, $n(\%)$ & $20(83.3)$ & $5(62.5)$ & $12(70.6)$ & $19(52.8)$ & 0.11 \\
\hline Antibiotics given at T0, $n(\%)$ & $24(100)$ & $7(87.5)$ & $16(94.1)$ & $32(88.9)$ & 0.38 \\
\hline Antibiotics adequate, $n$ (\%) & $23(95.8)$ & $7(87.5)$ & $16(94.1)$ & $27(75.0)$ & 0.10 \\
\hline Hydrocortisone, $n$ (\%) & $22(91.7)$ & $8(100)$ & $15(88.2)$ & $31(86.1)$ & 0.68 \\
\hline Transfusion RBC, $n(\%)$ & $4(16.7)$ & $3(37.5)$ & $3(17.6)$ & $4(11.1)$ & 0.35 \\
\hline \multicolumn{6}{|l|}{ Fluids and vasoactive agents } \\
\hline \multicolumn{6}{|l|}{ Fluids (ml), IQ 25 to 75} \\
\hline T0 & $2,039(1,343$ to 2,834$)$ & 1,934 (849 to 4,575) & $2,500(1,430$ to 3,628$)$ & $2,000(1,025$ to 3,153$)$ & 0.76 \\
\hline T6 & $4,733(3,196$ to 6,360$)$ & $4,082(1,576$ to 7,584$)$ & $4,845(2,550$ to 6,560$)$ & $4,673(3,380$ to 7,348$)$ & 0.83 \\
\hline \multicolumn{6}{|c|}{ Norepinephrine ( $\mu \mathrm{g} / \mathrm{kg} /$ minute), IQ 25 to $75, n$} \\
\hline T0 & 0.25 (0.19 to 0.36$), 24$ & 0.29 (0.14 to 1.20$), 6$ & 0.19 (0.10 to 0,37$), 16$ & 0.23 (0.10 to 0.38$), 30$ & 0.81 \\
\hline T6 & 0.20 (0.11 to 0.40$), 24$ & 0.36 (0.09 to 0.49), 6 & 0.12 (0.11 to 0.18$), 15$ & 0.19 (0.08 to 0.39$), 31$ & 0.45 \\
\hline \multicolumn{6}{|l|}{ Dopamine ( $\mu \mathrm{g} / \mathrm{kg} /$ minute), IQ 25 to $75, n$} \\
\hline T0 & - & 7.1 (7.1 to 7.3$), 2$ & 10.7 (10.7 to 10.7$), 1$ & 5.1 (2.8 to 6.6$), 5$ & 0.14 \\
\hline T6 & - & - & $8.0(8.0$ to 8.0$), 1$ & $5.3(2.5$ to 6.4$), 4$ & 0.16 \\
\hline \multicolumn{6}{|c|}{ Dobutamine ( $\mu \mathrm{g} / \mathrm{kg} / \mathrm{minute})$, IQ 25 to $75, n$} \\
\hline T0 & $3.1(2.7$ to 4.5$), 5$ & - & $5.9(5.1$ to 6.7$), 2$ & 3.3 (3.0 to 4.2$), 3$ & 0.15 \\
\hline T6 & 3.1 (2.7 to 5.6$), 3$ & - & $5.1(4.7$ to 6.3$), 4$ & 3.8 (3.3 to 4.8$), 3$ & 0.21 \\
\hline
\end{tabular}

$\mathrm{H}-\mathrm{H}$, venous-to-arterial carbon dioxide difference $\left(\mathrm{Pv}-\mathrm{aCO}{ }_{2}\right)$ high at T0 and T6; $\mathrm{L}-\mathrm{H}, \mathrm{Pv}-\mathrm{aCO}{ }_{2}$ normal at T0 and high at T6; $\mathrm{H}-\mathrm{L}, \mathrm{Pv}-\mathrm{aCO}{ }_{2}$ high at T0 and normal at T6; and L-L, Pv-aCO 2 normal at T0 and T6. APACHE, Acute Physiology and Chronic Health Evaluation; IQ 25 to 75, 25 to $75 \%$ interquartile range; RBC, red blood cells; T0, time 0; T6, 6 hours after Time 0.

Patients with elevated $\mathrm{Pv}-\mathrm{aCO}$ at $\mathrm{T} 6$ had slower lactate clearances at $\mathrm{T} 6$ and $\mathrm{T} 12$ than patients attaining a normal $\mathrm{Pv}-\mathrm{aCO} \mathrm{CO}_{2}$ during the first 6 hours of resuscitation (Figure 4). We also observed a significant linear correlation between mixed-venous to arterial $\mathrm{pCO}_{2}$ and central-venous to arterial $\mathrm{pCO}_{2}$ (Pearson correlation: 0.71, 95\% confidence interval: 0.47 to $0.86 ; P<0.001)$ but with moderate agreement between them $\left(R^{2}=0.556\right.$, $P<0.001$ ) (Figure 5). Additionally, significant differences were observed for the time course of $\mathrm{Pv}-\mathrm{aCO}_{2}$ and central venous-to-arterial carbon dioxide difference $\left(\mathrm{Pvc}-\mathrm{aCO}{ }_{2}\right)$ during the first 24 hours for survivor and nonsurvivors at day 28 (repeated-measures analysis of variance, $P=0.003$ and $P=0.03$, respectively; Figure S4a,b in Additional file 1).

Finally, patients who achieved $\mathrm{ScvO} 2 \geq 70 \%$ or $\mathrm{SvO} 2 \geq$ $65 \%$ but maintained high $\mathrm{Pv}-\mathrm{aCO} 2$ at $\mathrm{T} 0, \mathrm{~T} 6$ and $\mathrm{T} 12$ had a higher mortality risk at Day 28 (Table 3). 
Table 2 Hemodynamic, oxygen and ventilatory parameters

\begin{tabular}{|c|c|c|c|c|c|}
\hline Variable & $\begin{array}{l}\text { Group 1, H-H } \\
(n=24)\end{array}$ & $\begin{array}{l}\text { Group 2, L-H } \\
(n=8)\end{array}$ & $\begin{array}{l}\text { Group 3, H-L } \\
(n=17)\end{array}$ & $\begin{array}{l}\text { Group 4, L-L } \\
(n=36)\end{array}$ & $P$ value \\
\hline \multicolumn{6}{|c|}{ Hemodynamic variables } \\
\hline \multicolumn{6}{|c|}{ Heart rate (beats/minute) } \\
\hline TO & $112(103$ to 129$)$ & 111 (77 to 138$)$ & 104 (86 to 126$)$ & 109 (93 to 118$)$ & 0.31 \\
\hline T6 & 114 (101 to 125$)$ & 103 (73 to 127$)$ & 98 (85 to 114$)$ & 103 (88 to 118) & 0.14 \\
\hline \multicolumn{6}{|c|}{ Cardiac index $\left(\mathrm{l} / \mathrm{minute} / \mathrm{m}^{2}\right)$} \\
\hline TO & $3.0(2.3$ to 4.2$)$ & $3.6(2.7$ to 4.6$)$ & $3.0(2.5$ to 5.0$)$ & $3.5(2.7$ to 4.5$)$ & 0.63 \\
\hline T6 & $3.2(2.2$ to 4.3$)$ & 3.3 (2.4 to 3.8$)$ & 3.7 (2.2 to 5.5$)$ & 3.6 (2.8 to 4.3$)$ & 0.75 \\
\hline \multicolumn{6}{|c|}{ MAP $(\mathrm{mmHg})$} \\
\hline T0 & $65.0(61.0 \text { to } 72.8)^{* *}$ & $67.0(65.3$ to 69.5$)$ & $73.0(68.0 \text { to } 82.5)^{* *}$ & $72.0(64.5$ to 77.0$)$ & 0.02 \\
\hline T6 & $69.0(65.3$ to 75.8$)$ & 77.5 (70.5 to 96.0$)$ & $68.0(63.5$ to 72.0$)$ & 71.5 (65.0 to 78.8$)$ & 0.06 \\
\hline \multicolumn{6}{|c|}{ CVP $(\mathrm{mmHg})$} \\
\hline T0 & $14.5(10.3$ to 17.0$)$ & 10.0 (9.0 to 12.8$)$ & $12.0(8.5$ to 15.0$)$ & $10.0(7.0$ to 14.0$)$ & 0.10 \\
\hline T6 & $13.5(10.0 \text { to } 15.8)^{* *}$ & $15.0(10.0$ to 17.0$)$ & $10.0(5.0 \text { to } 12.5)^{* *}$ & $10.0(7.3$ to 13.0$)$ & 0.03 \\
\hline \multicolumn{6}{|c|}{ PAOP $(\mathrm{mmHg})$} \\
\hline TO & $17.0(14.0$ to 20.0$)$ & 12.5 (10.0 to 15.0$)$ & 17.0 (12.0 to 22.0$)$ & 15.0 (11.0 to 20.0$)$ & 0.52 \\
\hline T6 & $19.0(15.0 \text { to } 24.0)^{* *}$ & 14.5 (10.0 to 19.0$)$ & $13.0(10.0 \text { to } 15.0)^{* *}$ & $16.0(12.0$ to 20.0$)$ & 0.03 \\
\hline \multicolumn{6}{|c|}{ Blood gases and oxygen variables } \\
\hline \multicolumn{6}{|l|}{$\mathrm{pH}$} \\
\hline TO & 7.30 (7.18 to 7.37$)$ & 7.31 (7.22 to 7.40$)$ & 7.34 (7.22 to 7.41$)$ & 7.32 (7.24 to 7.40$)$ & 0.85 \\
\hline T6 & 7.32 (7.20 to 7.36$)$ & 7.35 (7.30 to 7.42$)$ & 7.35 (7.26 to 7.39$)$ & 7.34 (7.30 to 7.39$)$ & 0.33 \\
\hline \multicolumn{6}{|c|}{$\mathrm{PaCO}_{2}(\mathrm{mmHg})$} \\
\hline TO & 30.5 (24.1 to 36.6$)$ & $34.2(24.7$ to 36.9$)$ & 31.0 (23.6 to 33.6$)$ & 27.5 (23.7 to 36.5$)$ & 0.81 \\
\hline T6 & 26.1 (22.4 to 32.7 ) & $31.0(21.6$ to 34.0$)$ & 31.3 (26.8 to 33.6$)$ & $27.5(21.7$ to 32.1$)$ & 0.25 \\
\hline \multicolumn{6}{|c|}{$\mathrm{PvmCO}_{2}(\mathrm{mmHg})$} \\
\hline TO & $40.6(33.9 \text { to } 46.5)^{\pi}$ & 29.5 (25.0 to 35.3$)$ & 39.7 (35.5 to 47.1$) 34.3$ & $32.8(27.3 \text { to } 40.9)^{\pi}$ & 0.03 \\
\hline T6 & $38.0(29.9 \text { to } 39.7)^{\text {๓ }}$ & 38.3 (28.0 to 46.2 ) & (30.4 to 36.8 ) & 30.0 (25.5 to 35.5$)^{\natural}$ & 0.02 \\
\hline \multicolumn{6}{|c|}{$\mathrm{PvcCO}_{2}(\mathrm{mmHg})$} \\
\hline T0 & 38.2 (29.1 to 50.5$)$ & 40.1 (34.2 to 43.4$)$ & 36.7 (35.5 to 47.1$) 33.9$ & 32.5 (28.1 to 38.4$)$ & 0.12 \\
\hline T6 & 33.7 (28.3 to 36.9$)$ & $33.8(31.4$ to 41.4$)$ & (30.4 to 36.8$)$ & 29.0 (25.1 to 35.8$)$ & 0.20 \\
\hline \multicolumn{6}{|c|}{$\mathrm{PaO}_{2}(\mathrm{mmHg})$} \\
\hline T0 & 112.2 (79.3 to 167.3$)$ & 117.1 (77.5 to 139.5$)$ & 115.7 (81.4 to 140.8$)$ & $100(86.0$ to 123.9$)$ & 0.70 \\
\hline T6 & 113.6 (83.0 to 147.3$)$ & 132.5 (109.8 to 197.8$)$ & $105.0(83.5$ to 127.4$)$ & 111.5 (86.2 to 135.7) & 0.34 \\
\hline \multicolumn{6}{|c|}{$\mathrm{PaO}_{2} / \mathrm{FiO}_{2}(\mathrm{mmHg})$} \\
\hline TO & 188.9 (117.1 to 265.0$)$ & 166.9 (143.8 to 244.1) & 233.7 (184.6 to 314.0) & 214.3 (141.6 to 368.0) & 0.28 \\
\hline T6 & 177.9 (136.4 to 298.4) & 265.0 (185.5 to 383.5$)$ & 239.3 (185.1 to 306.3) & 253.5 (181.6 to 368.0) & 0.17 \\
\hline \multicolumn{6}{|c|}{ Lactate (mmol/l) } \\
\hline TO & 4.3 (2.0 to 7.9$)$ & 2.9 (2.0 to 9.7 ) & 2.7 (1.5 to 3.9$)$ & 2.9 (1.7 to 4.7$)$ & 0.16 \\
\hline T6 & $3.3(2.1 \text { to } 6.8)^{* * \pi}$ & $2.9(1.1$ to 7.1$)$ & $1.3(0.9 \text { to } 2.3)^{* *}$ & $2.0(1.0 \text { to } 3.5)^{\natural}$ & 0.002 \\
\hline \multicolumn{6}{|l|}{$\mathrm{ScvO}_{2}(\%)$} \\
\hline TO & $64.0(54.7$ to 75.1$)$ & 66.8 (59.7 to 74.5$)$ & 73.0 (70.8 to 76.7$)$ & 67.1 (62.1 to 75.9$)$ & 0.36 \\
\hline T6 & 70.8 (66.4 to 73.5 ) & 73.4 (69.3 to 78.0$)$ & $72.3(67.2$ to 75.9$)$ & $76.0(60.0$ to 77.9$)$ & 0.53 \\
\hline \multicolumn{6}{|l|}{$\mathrm{SvO}_{2}(\%)$} \\
\hline TO & $66.0(56.8$ to 71.4$)$ & $68.0(54.9$ to 81.0$)$ & 68.1 (57.0 to 71.0$)$ & 69.7 (62.1 to 75.9$)$ & 0.39 \\
\hline
\end{tabular}


Table 2 Hemodynamic, oxygen and ventilatory parameters (Continued)

\begin{tabular}{|c|c|c|c|c|c|}
\hline T6 & 69.0 (63.3 to 72.9$)$ & 70.6 (63.4 to 73.8$)$ & 71.2 (64.4 to 75.1) & 68.0 (58.7 to 74.3$)$ & 0.77 \\
\hline \multicolumn{6}{|c|}{ Oxygen extraction ratio } \\
\hline TO & 34.7 (28.3 to 44.3 ) & 30.8 (22.7 to 38.4 ) & 29.4 (25.0 to 36.8 ) & 30.7 (24.9 to 37.5$)$ & 0.36 \\
\hline T6 & 29.8 (26.4 to 36.6) & 30.2 (24.9 to 31.3 ) & 29.3 (24.1 to 33.3) & 30.7 (23.4 to 39.3) & 0.68 \\
\hline \multicolumn{6}{|l|}{$\mathrm{Pv}-\mathrm{aCO}{ }_{2}(\mathrm{mmHg})$} \\
\hline TO & $8.2(7.0 \text { to } 10.6)^{* \pi}$ & $1.4(1.1 \text { to } 5.3)^{* \varphi}$ & $6.3(6.1 \text { to } 7.2)^{\varphi \xi}$ & $2.7(2.0 \text { to } 4.0)^{\Uparrow \varepsilon}$ & $<0.001$ \\
\hline T6 & $7.6(6.4 \text { to } 9.4)^{* * \text { ก }}$ & $8.6(6.5 \text { to } 11.7)^{\varphi \Psi}$ & $3.5(0.9 \text { to } 4.3)^{* * \varphi}$ & $3.3(2.2 \text { to } 4.1)^{\mathbb{9} \psi}$ & $<0.001$ \\
\hline \multicolumn{6}{|c|}{ Pvc-aCO $2(\mathrm{mmHg})$} \\
\hline T0 & $9.7(7.0 \text { to } 12.1)^{\pi}$ & $4.6(3.3$ to 6.1$)$ & 7.3 (4.6 to 9.1$)$ & $4.4(2.7 \text { to } 5.4)^{n}$ & $<0.001$ \\
\hline T6 & 7.0 (5.8 to 9.7$)$ & $8.5(5.6 \text { to } 9.6)^{\psi}$ & 4.4 (2.1 to 5.5$)$ & $4.0(1.7 \text { to } 5.4)^{\psi}$ & 0.003 \\
\hline \multicolumn{6}{|c|}{ Ventilatory parameters } \\
\hline \multicolumn{6}{|c|}{ Mechanical ventilation } \\
\hline T0 & 24 & 5 & 11 & 23 & 0.01 \\
\hline T6 & 24 & 5 & 11 & 23 & 0.01 \\
\hline PEEP $(m m H g), n$ & & & 5.0 (5.0 to 8.0$), 11$ & 6.0 (5.0 to 8.0), 23 & 0.48 \\
\hline TO & $6.0(5.0$ to 8.0$), 24$ & 5.0 (5.0 to 6.0$), 5$ & 5.0 (5.0 to 8.0$), 11$ & 8.0 (5.0 to 10.0), 23 & \\
\hline T6 & 6.5 (5.0 to 8.0$), 24$ & $5.0(5.0$ to 7.5$), 5$ & & & \\
\hline \multicolumn{6}{|c|}{ Tidal volume $(\mathrm{ml} / \mathrm{kg})$} \\
\hline T0 & 7.1 (6.3 to 7.7$)$ & 7.3 (6.3 to 7.6$), 5$ & 7.0 (6.5 to 8.0$), 11$ & 7.5 (6.6 to 8.0), 23 & 0.65 \\
\hline T6 & $7.2(6.3$ to 7.9$)$ & 7.2 (6.6 to 7.6$), 5$ & 7.5 (6.8 to 8.0$), 11$ & 7.5 (6.9 to 8.0), 23 & 0.65 \\
\hline
\end{tabular}

Data presented as mean ( 25 to $75 \%$ interquartile range). $C V P$, central venous pressure; $\mathrm{FiO}_{2}$, oxygen inspired fraction; $M A P$, mean arterial pressure; PaCO ${ }_{2}$, arterial carbon dioxyde pressure; $\mathrm{PaO} 2$, arterial oxygen pressure; $P A O P$, pulmonary artery occlusion pressure; $\mathrm{PEEP}$, positive end-expiratory pressure; $P v$ - $a C \mathrm{C}_{2}$, mixed venous-to-arterial carbon dioxide difference; $P v c-a C_{2}$, central venous-to-arterial carbon dioxide difference; $P v c \mathrm{CO}_{2}$, central venous carbon dioxide pressure; $P v m C \mathrm{C}_{2}$, mixed venous carbon dioxide pressure; $\mathrm{SCVO}_{2}$, central venous oxygen saturation; $\mathrm{SvO}_{2}$, mixed venous oxygen saturation; T0, time 0; T6, 6 hours after Time 0 . * $P<0.05$ for Groups 1 vs. 2; ${ }^{* *} P<0.05$ for Groups 1 vs. 3 ; ${ }^{9} P<0.05$ for Groups 1 vs. $4{ }^{\varphi}{ }^{\varphi} P<0.05$ for Groups 2 vs. 3 ; ${ }^{\psi} P<0.05$ for Groups 2 vs. 4 ; and ${ }^{\xi} P<0.05$ for Groups 3 vs. 4.

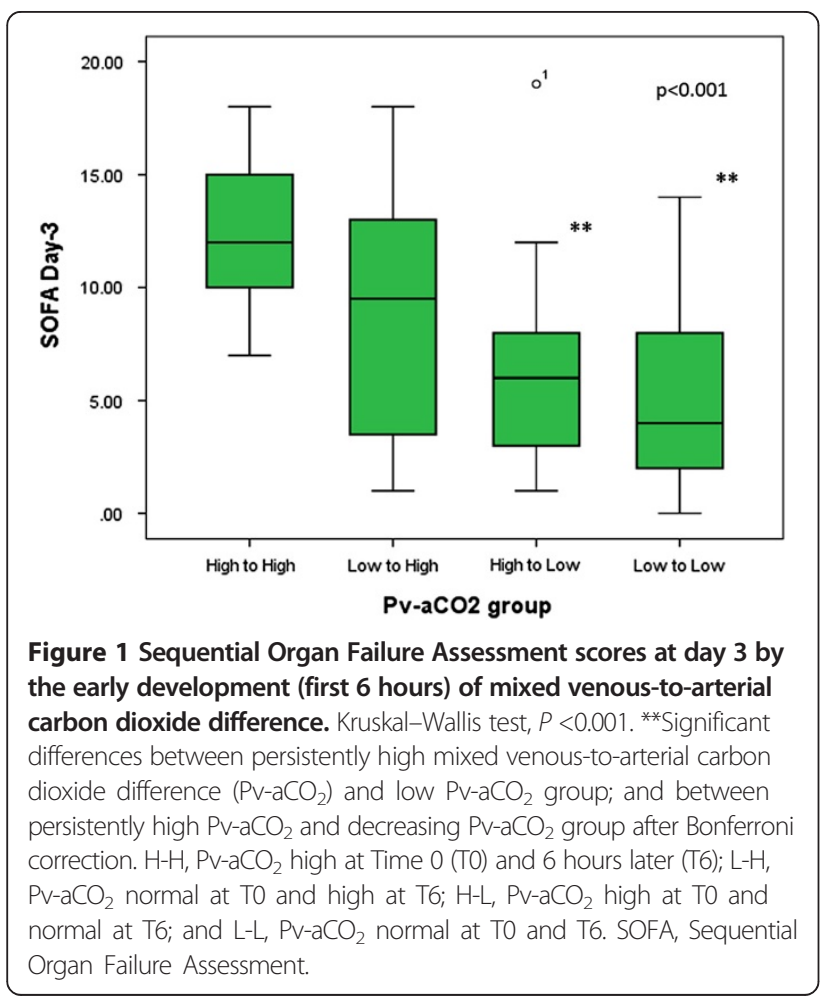

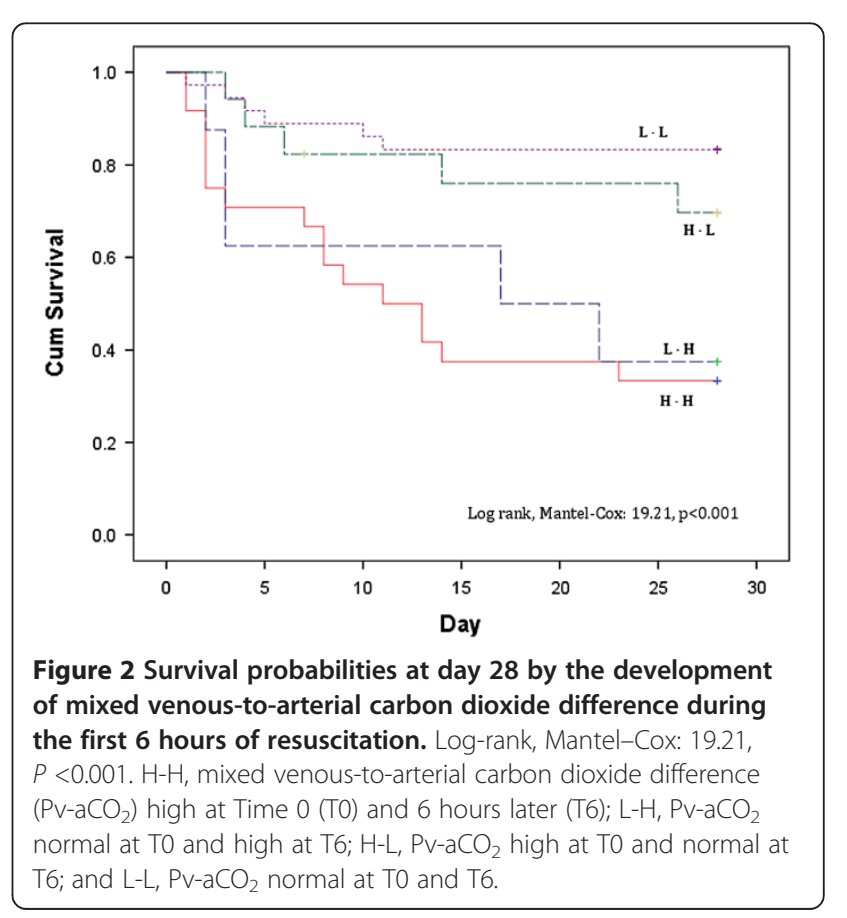




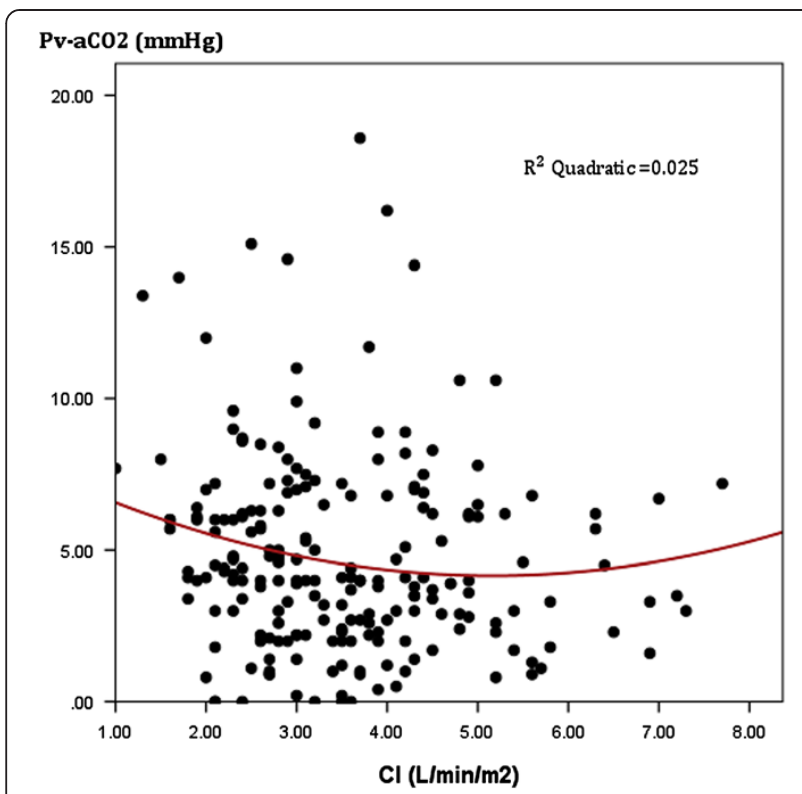

Figure 3 Scatter plot between cardiac index and mixed venousto-arterial carbon dioxide difference. All patients at Time 0 (TO) and 6 hours (T6), 12 hours (T12) and 24 hours (T24) later. Pearson correlation: $0.16 ; r^{2}=0.025 ; P<0.01 . \mathrm{Cl}$, confidence interval; $\mathrm{PV}-\mathrm{aCO}_{2}$, mixed venous-to-arterial carbon dioxide difference.

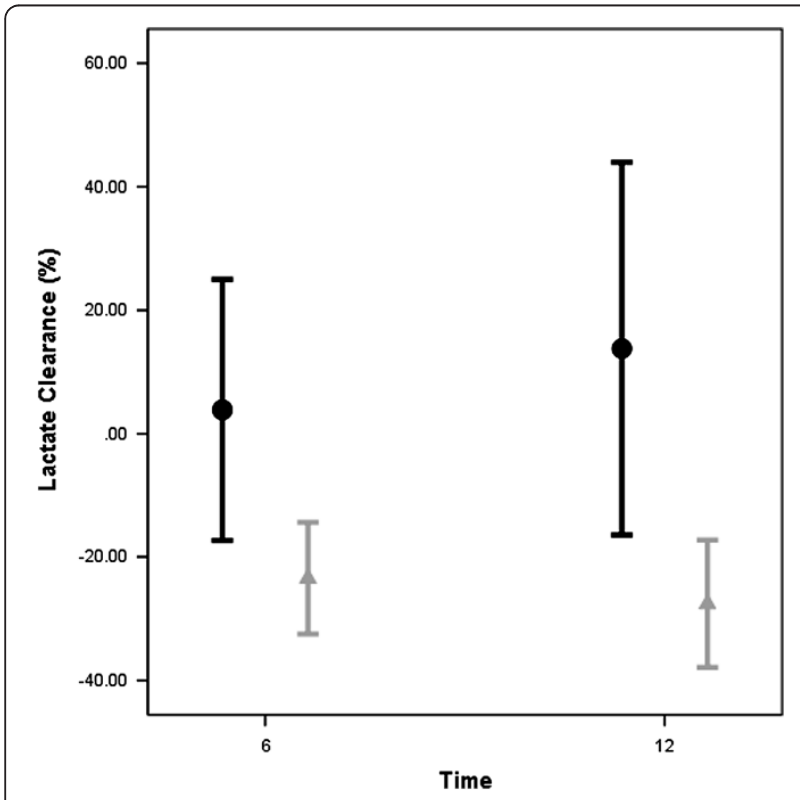

Figure 4 Lactate clearance (\%) 6 and 12 hours after Time 0 for patients with normal or high mixed venous-to-arterial carbon dioxide difference at 6 hours. Significant differences for lactate clearance (Time 0 (T0) to 6 hours later (T6) and T0 to 12 hours later (T12)) between patients with persistently high (that is, high-to-high and normal-to-high groups) and normalized mixed venous-to-arterial carbon dioxide difference at T6 (high-to-normal and persistently low groups). A negative percent clearance indicates a reduction in lactate levels. Black bars: High Pv-aCO 2 at T6; Gray bars: Low Pv-aCO 2 at T6.

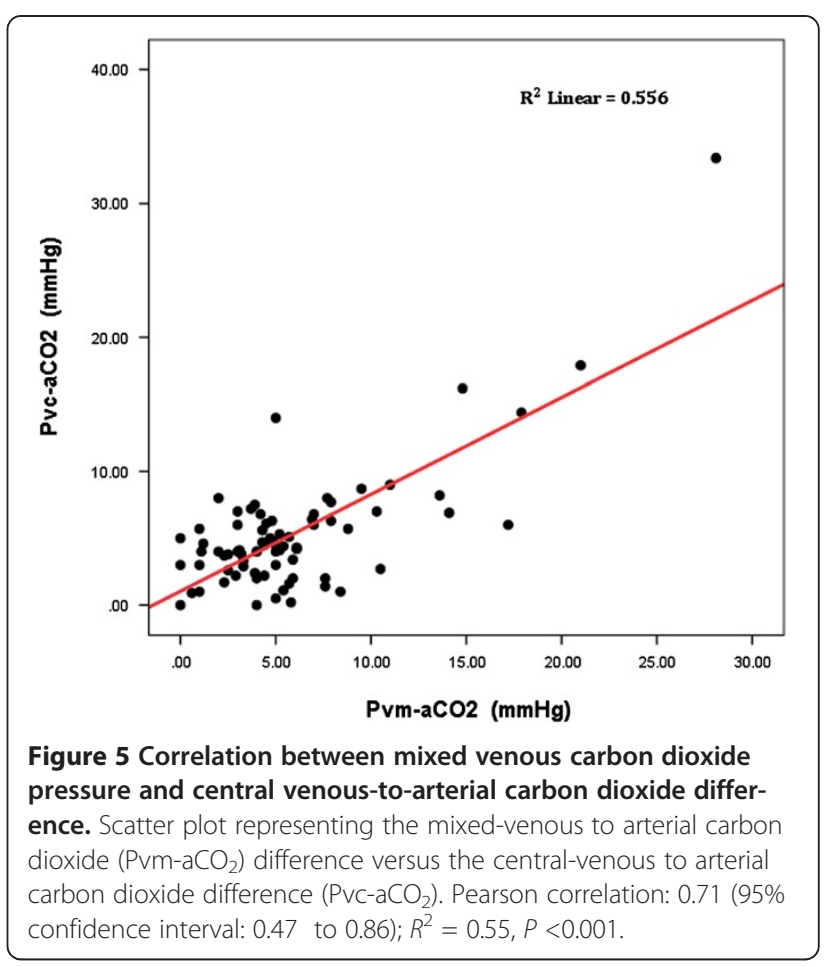

\section{Discussion}

We studied a cohort of patients during the very early phases of septic shock who were subjected to a comprehensive resuscitation aimed to target the usual hemodynamic and oxygen metabolism parameters. A recent study demonstrated how $\mathrm{Pv}-\mathrm{aCO}$ could be a tool to detect persistent inadequate resuscitation during septic shock [18] although it was not conducted during very early stages of resuscitation. Even a faster enrollment, our study showed that a number of patients had approximately normal $\mathrm{SvO}_{2}$ and $\mathrm{ScvO}_{2}$ at catheter insertion as it has been reported at ICU admission [22], and most of them reached normal oxygen-derived parameters at 6 hours. However, despite attaining the $\mathrm{SvO}_{2}$ and $\mathrm{ScvO}_{2}$ targets (and after adjusting for $\mathrm{SvO}_{2}$ ) and an apparent global hemodynamic normalization in most patients, those with persistently high $\mathrm{Pv}-\mathrm{aCO}_{2}$ developed more severe multiorgan dysfunction at day 3 than patients evolving with normal $\mathrm{Pv}-\mathrm{aCO}_{2}$ during the first 6 hours of

Table 3 Mortality risk ratio for patients with mixed oxygen saturation $\geq 65 \%$ but with mixed venous-to-arterial carbon dioxide difference $\geq 6 \mathbf{m m H g}$ at day 28

\begin{tabular}{lccc}
\hline Time & ${\text { Relative } \text { risk }^{\mathbf{a}}}$ & Confidence interval & $\boldsymbol{P}$ value \\
\hline 0 hours & 1.77 & $0.97-3.22$ & 0.06 \\
6 hours & 2.23 & $1.20-4.13$ & 0.01 \\
12 hours & 2.41 & $1.42-4.10$ & 0.001 \\
\hline
\end{tabular}

${ }^{a}$ Relative mortality risk at day 28 . 
resuscitation or those who evolved from high to normal $\mathrm{PvaCO}_{2}$. Additionally, we observed that persistently high $\mathrm{Pv}-\mathrm{aCO}_{2}$ was associated with a lower survival at day 28.

Venous hypercarbia is a marker of limited blood flow during cardiac arrest and shock states [8-19]. Recent observations have suggested that $\mathrm{Pv}-\mathrm{aCO}_{2}$ might identify septic patients who remain inadequately resuscitated despite achieving $\mathrm{ScrO}_{2}$ goals [15]. Consistent with these findings, we found that patients in septic shock achieving $\mathrm{ScvO}_{2} \geq 70 \%$ or $\mathrm{SvO}_{2} \geq 65 \%$ had worse outcomes when a concomitant high $\mathrm{Pv}-\mathrm{aCO}_{2}$ was observed. These data reinforce the idea that $\mathrm{Pv}-\mathrm{aCO}_{2}$ provides additional information to hemodynamic and oxygen parameters habitually used during resuscitation of septic shock. Nevertheless, the underlying mechanisms that explain increases in $\mathrm{Pv}-\mathrm{aCO}_{2}$ during septic shock are incompletely understood; however, to current knowledge, an increased $\mathrm{Pv}-\mathrm{aCO}_{2}$ results from the interactions between blood flow to the tissues, aerobic and anaerobic $\mathrm{CO}_{2}$ generation, and the $\mathrm{CO}_{2}$ dissociation curve.

According to the Fick equation, during steady state the $\mathrm{CO}_{2}$ excretion equals the product of cardiac output by the difference between mixed venous blood $\mathrm{CO}_{2}$ content and arterial blood $\mathrm{CO}_{2}$ content. Some studies have emphasized on the key role of cardiac output on venous to arterial $\mathrm{CO}_{2}$ content differences and indeed a curvilinear relationship between these two variables has been described [14]. However, in our study we found a poorer concordance between cardiac output and $\mathrm{Pv}-\mathrm{aCO}_{2}$ at each time point of resuscitation (Figure 3) and, in fact, the cardiac output remained normal or even high during the first 24 hours of resuscitation (Figure S2 in Additional file 1), suggesting some independence between $\mathrm{Pv}_{\mathrm{aCO}}$ and macrovascular blood flow changes. While in noninflammatory low-flow states tissue and regional hypercarbia can be easily explained by the $\mathrm{CO}_{2}$ stagnation phenomenon $[15,16]$, the interpretation of an increased tissue and/or regional $\mathrm{CO}_{2}$ during inflammatory conditions is more complex. Sepsis may thereby be associated with the coexistence of normal or even high cardiac output, inter-organ and intra-organ blood flow redistribution, and altered microvascular and oxygen extraction capabilities. All of these alterations can influence the tissue $\mathrm{CO}_{2}$ production and elimination.

A study by Neviere and colleagues thus demonstrated the key role of microvascular blood flow on gastric $\mathrm{CO}_{2}$ accumulation [27]. Similarly, using simultaneous gastric tonometry and laser Doppler flowmetry, Elizalde and colleagues demonstrated the association between gastric mucosal $\mathrm{pH}$ and mucosal blood flow, regardless of macrohemodynamic variations [28]. Likewise, Tugtekin and colleagues demonstrated in a porcine sepsis model that the increase of mucosal to arterial $\mathrm{CO}_{2}$ gap was related to the heterogeneity of gut mucosal blood flow, even though cardiac output and mesenteric blood flow were maintained [29]. Meanwhile, Creteur and colleagues found a significant correlation among sublingual $\mathrm{CO}_{2}$, gastric mucosal $\mathrm{CO}_{2}$ and microcirculatory heterogeneity in human septic shock during dobutamine infusion, and suggested that the primary determinant of tissue $\mathrm{CO}_{2}$ accumulation was the microcirculatory blood flow [30]. Hence, there is an evident link between blood flow and tissue or local $\mathrm{CO}_{2}$ accumulations conducting to increase tissue or venous-to-arterial $\mathrm{CO}_{2}$ differences, but sometimes normal macrohemodynamics does not prevent elevation of $\mathrm{Pv}-\mathrm{aCO}$. The near normalization of the oxygen and hemodynamic parameters between the subgroups in our study suggests that venous $\mathrm{CO}_{2}$ accumulation encloses more complex mechanisms than macrovascular stagnation, and we could hypothesize that microvascular blood flow distribution is one of several factors potentially influencing the behavior of $\mathrm{Pv}-\mathrm{aCO}$ during inflammatory conditions in which the heterogeneity of microvascular blood flow is increased. However, this hypothesis should be confirmed in future studies.

The interpretation of hyperlactatemia in sepsis is very complex, especially in septic shock [31] since anaerobic metabolism, non-anaerobic generation and slow clearance can conduct lactate accumulation. We observed higher lactate levels and slower lactate clearance at T6 and $\mathrm{T} 12$ in patients with persistently high $\mathrm{Pv}-\mathrm{aCO}_{2}$ during the first 6 hours of resuscitation. Interestingly, $\mathrm{Pv}$ $\mathrm{aCO}_{2}$ (and $\mathrm{Pvc}-\mathrm{aCO}_{2}$ ) kinetics seems to anticipate a slower lactate clearance (Figure S5 in Additional file 1). A high $\mathrm{Pv}-\mathrm{aCO}_{2}$ could indicate a decrease in global or microvascular blood flow conducting to slow lactate clearance. However, a high $\mathrm{Pv}-\mathrm{aCO}_{2}$ could also reflect the persistence of anaerobic metabolism as result of bicarbonate buffering of protons derived from fixed acids [32]. Thus, an increased $\mathrm{Pv}-\mathrm{aCO}$ to oxygen consumption ratio could reflect global anaerobic metabolism as was proposed by Mekontso-Dessap and colleagues [19]. However, even in the presence of anaerobic metabolism, a high efferent venous blood flow could be sufficient to wash out the global $\mathrm{CO}_{2}$ generation from the hypoperfused peripheral tissues and, in this case, $\mathrm{Pv}-\mathrm{aCO}$ could not increase. In fact, hypoperfusion could persist in some of our patients and even oxygen parameters, global hemodynamics or $\mathrm{Pv}-\mathrm{aCO}_{2}$ remain normal.

Finally, we found a significant linear correlation but moderate agreement between venous-arterial $\mathrm{CO}_{2}$ differences obtained from mixed venous and central venous samples that agree with recent observations published simultaneously to the review of our paper [21]. Even though $\mathrm{Pvc}-\mathrm{aCO}_{2}$ can be easily obtained and speedily usable in the emergency room, the point about whether $\mathrm{Pvc}-\mathrm{aCO}_{2}$ and mixed venous carbon dioxide pressure 
$\left(\mathrm{Pv}-\mathrm{aCO}_{2}\right.$ in our study) are really interchangeable should be addressed in future studies.

Our study has some limitations. First, our observations are restricted to macro-hemodynamic variables, and Pv$\mathrm{aCO}_{2}$ is another global variable that does not necessarily represent tissue or regional vascular perfusion at different beds. We did not describe regional perfusion variables as gastric tonometry or local tissue $\mathrm{CO}_{2}$ accumulation; hence, normal $\mathrm{Pv}-\mathrm{aCO}_{2}$ might also occur when regional hypoperfusion is ongoing.

Second, we suggest that persistently high $\mathrm{Pv}-\mathrm{aCO} \mathrm{CO}_{2}$ reflects tissue or regional hypoperfusion. We hypothesized that $\mathrm{Pv}-\mathrm{aCO}$ could reflect the venous $\mathrm{CO}_{2}$ accumulation due to the heterogeneous microcirculatory blood flow when cardiac output and oxygen parameters remain normal or even high or, eventually, $\mathrm{Pv}-\mathrm{aCO}_{2}$ could reflect anaerobic $\mathrm{CO}_{2}$ generation. However, mechanism conducting to venous $\mathrm{CO}_{2}$ accumulation during inflammatory conditions should be explored in future studies.

Third, during conditions of tissue hypoxia but with preserved blood flow (even though during anaerobic metabolism carbon dioxide production - $\mathrm{VCO}_{2}$ - decreases less than oxygen consumption $-\mathrm{VO}_{2}-$ ), venous blood flow might be high enough to ensure adequate washout of the $\mathrm{CO}_{2}$ produced by hypoxic cells, thereby preventing a $\mathrm{Pv}-\mathrm{aCO} 2$ increase.

Fourth, we assumed that a linear relationship exist between partial $\mathrm{CO}_{2}$ pressure and $\mathrm{CO}_{2}$ content at the venous and arterial levels [33,34]. $\mathrm{Pv}-\mathrm{aCO}{ }_{2}$ could thus be used as a surrogate for the $\mathrm{Cv}-\mathrm{aCO}_{2}$. However, previous research has shown that the Haldane effect causes paradoxical increases in $\mathrm{Pv}-\mathrm{aCO}{ }_{2}$ during blood flow increases [33,34]. Unfortunately, the calculation of $\mathrm{CO}_{2}$ content is complex and subject to errors due to the number of variables included in the formulas. Simplified formulas are easy to use, but wide differences in venous and arterial acid-base status (for example, ischemic hypoxia) can preclude their use. Nevertheless, some authors consider that the Haldane effect exerts a minor influence, and in most cases $\mathrm{Pv}-\mathrm{aCO}_{2}$ and $\mathrm{CO}_{2}$ content differences develop similarly [35].

Finally, our observations were restricted to a small sample of patients in septic shock. Although our findings seem logical and biologically plausible, they should be confirmed in future studies.

\section{Conclusions}

The persistence of high $\mathrm{Pv}-\mathrm{aCO}$ during the early resuscitation of patients in septic shock is associated with significant higher multiorgan dysfunction and poor outcomes. Although underlying mechanisms that increase $\mathrm{Pv}-\mathrm{aCO}_{2}$ among patients in septic shock must be clarified, $\mathrm{Pv}-\mathrm{aCO}_{2}$ might identify a high risk of death in apparently resuscitated patients. Future studies should test $\mathrm{Pv}-\mathrm{aCO}_{2}$ as a perfusion goal during early phases of the resuscitation of patients in septic shock.

\section{Key messages}

- Persistent high $\mathrm{Pv}-\mathrm{aCO}$ is related to more severe multiorgan dysfunction and worse outcomes in apparently resuscitated septic shock patients.

- Mechanisms conducting to increase $\mathrm{Pv}-\mathrm{aCO}_{2}$ during inflammatory conditions are insufficiently understood.

Variations in $\mathrm{Pv}-\mathrm{aCO}$ were independent of macro-flow variables (that is, cardiac output) or oxygen metabolism targets (that is, SvO2, oxygen extraction rate), suggesting that venous stagnation is not the single explanation for venous $\mathrm{CO}_{2}$ accumulation.

- $\mathrm{Pv}-\mathrm{aCO} \mathrm{CO}_{2}$ might identify a high risk of death in apparently resuscitated septic shock patients, and could be explored as a tissue perfusion goal during resuscitation as $\mathrm{Pv}-\mathrm{aCO} \mathrm{CO}_{2}$ tracks ischemic hypoxia.

\section{Additional file}

Additional file 1: Figure S1a presenting the time course of $\mathrm{ScvO2}$ (\%) during the first $\mathbf{2 4}$ hours for survivors and nonsurvivors at day-28. Figure S1b presenting the time course of SvO2 (\%) during the first 24 hours for survivors and nonsurvivors at day 28. Figure S2 presenting the time course of cardiac output ( $1 /$ minute) during the first 24 hours for survivors and nonsurvivors at day 28. Figure $\mathbf{S 3}$ presenting the scatter plot between cardiac index and $\mathrm{P} v-\mathrm{aCO}_{2}$ (according to $\mathrm{Pv}_{\mathrm{aCO}}$ at T6). Figure S4a presenting the time course of $\mathrm{PV}-\mathrm{aCO} 2(\mathrm{mmHg})$ during the first 24 hours for survivors and nonsurvivors at day 28. Figure S4b presenting the time course of Pvc-aCO2 $(\mathrm{mmHg})$ during the first 24 hours for survivors and nonsurvivors at day 28. Figure S5 presenting the time course of lactate levels ( $\mathrm{mmol} / \mathrm{l})$ during the first 24 hours for survivors and nonsurvivors at day 28.

\section{Abbreviations}

$\mathrm{CO}_{2}$ : Carbon dioxide; $\mathrm{Pv}-\mathrm{aCO}$ : Mixed venous-to-arterial carbon dioxide difference; Pvc-aCO 2 : Central venous-to-arterial carbon dioxide difference; $\mathrm{S}_{\mathrm{CVO}}$ : Central venous oxygen saturation; $\mathrm{SvO}_{2}$ : Mixed venous oxygen saturation.

\section{Competing interests}

The authors declare they have no competing interests.

\section{Authors' contributions}

GAO-T contributed to the study conception, design and manuscript preparation. DFB-R, MU, JDT, AG and WB were involved in data collection and revising the manuscript. $A F G, M G, C A-D$ and $G H$ revised the manuscript critically. All authors read and approved the final manuscript.

\section{Acknowledgments}

The authors thank Dr Magda Cepeda (Fundación Valle del Lili, Cali, Colombia), Dr Oscar Ramírez W (Fundación Valle del Lili, Cali, Colombia) and Dr Yoseth Ariza (Universidad ICESI, Cali, Colombia) for their contributions to the statistical analyses.

\section{Author details}

${ }^{1}$ Intensive Care Unit, Fundación Valle del Lili, Av. Simón Bolívar Cra. 98, Cali, Colombia. ${ }^{2}$ Biomedica Research Group, Universidad ICESI, Cali, Colombia. ${ }^{3}$ Departamento de Medicina Intensiva, Pontificia Universidad Católica de Chile, Santiago, Chile. 
Received: 19 June 2013 Accepted: 21 October 2013

Published: 13 December 2013

\section{References}

1. Beal AL, Cerra FB: Multiple organ failure syndrome in the, 1990's. Systemic inflammatory response and organ dysfunction. JAMA 1990, 1994:226-233.

2. Shoemaker WC, Appel PL, Kram HB: Tissue oxygen debt as a determinant of lethal and nonlethal postoperative organ failure. Crit Care Med 1988, 16:1117-1120

3. Vallet B: Vascular reactivity and tissue oxygenation. Intensive Care Med 1998, 24:3-11.

4. Rivers E, Nguyen B, Havstad S, Ressler J, Muzzin A, Knoblich B, Peterson E, Tomlanovich M: Early goal-directed therapy in the treatment of severe sepsis and septic shock. N Eng J Med 2001, 345:1368-1377.

5. Third European Consensus Conference in Intensive Care Medicine: Tissue hypoxia: How to detect, how to correct, how to prevent. Societe de reanimation de langue francaise. The American thoracic society. European society of intensive care medicine. Am J Respir Crit Care Med 1996, 154:1573-1578.

6. Russell JA, Phang PT: The oxygen delivery/consumption controversy. Approaches to management of the critically ill. Am J Respir Crit Care Med 1994, 149:533-537

7. Marik PE, Bankov A: Sublingual capnometry versus traditional markers of tissue oxygenation in critically ill patients. Crit Care Med 2003, 31:818-822.

8. Grundler W, Weil MH, Rackow EC: Arteriovenous carbon dioxide and pH gradients during cardiac arrest. Circulation 1986, 74:1071-1074.

9. Weil MH, Rackow EC, Trevino R, Grundler W, Falk JL, Griffel MI: Difference in acid-base state between venous and arterial blood during cardiopulmonary resuscitation. N Engl J Med 1986, 315:153-156.

10. Mecher CE, Rackow EC, Astiz ME, Weil MH: Venous hypercarbia associated with severe sepsis and systemic hypoperfusion. Crit Care Med 1990, 18:585-589

11. Adrogue HJ, Rashad MN, Gorin AB, Yacoub J, Madias NE: Assessing acid-base status in circulatory failure. Differences between arterial and central venous blood. N Engl J Med 1989, 320:1312-1316

12. Kazarian KK, Del Guercio LR: The use of mixed venous blood gas determinations in traumatic shock. Ann Emerg Med 1980, 9:179-182.

13. Teboul JL, Mercat A, Lenique F, Berton C, Richard C: Value of the venousarterial PCO2 gradient to reflect the oxygen supply to demand in humans: effects of dobutamine. Crit Care Med 1998, 26:1007-1010.

14. Bakker J, Vincent JL, Gris P, Leon M, Coffernils M, Kahn RJ: Veno-arterial carbon dioxide gradient in human septic shock. Chest 1992, 101:509-515.

15. Vallet B, Teboul JL, Cain S, Curtis S: Venoarterial CO(2) difference during regional ischemic or hypoxic hypoxia. J Appl Physiol 2000, 89:1317-1321.

16. Neviere $R$, Chagnon $J L$, Teboul $J$, Vallet B, Wattel F: Small intestine intramucosal $\mathrm{PCO}(2)$ and microvascular blood flow during hypoxic and ischemic hypoxia. Crit Care Med 2002, 30:379-384.

17. Dubin A, Estenssoro E, Murias G, Pozo MO, Sottile JP, Baran M, Piacentini E, Canales HS, Etcheverry G: Intramucosal-arterial Pco2 gradient does not reflect intestinal dysoxia in anemic hypoxia. J Trauma 2004, 57:1211-1217.

18. Vallee F, Vallet B, Mathe O, Parraguette J, Mari A, Silva S, Samii K, Fourcade O, Genestal M: Central venous-to-arterial carbon dioxide difference: an additional target for goal-directed therapy in septic shock? Intensive Care Med 2008, 34:2218-2225.

19. Mekontso-Dessap A, Castelain V, Anguel N, Bahloul M, Schauvliege F, Richard C, Teboul JL: Combination of venoarterial PCO2 difference with arteriovenous $\mathrm{O} 2$ content difference to detect anaerobic metabolism in patients. Intensive Care Med 2002, 28:272-277.

20. van Beest PA, van Ingen J, Boerma EC, Holman ND, Groen H, Koopmans M, Spronk PE, Kuiper MA: No agreement of mixed venous and central venous saturation in sepsis, independent of sepsis origin. Crit Care Med 2010, 14:R219.

21. van Beest PA, Lont MC, Holman ND, Loef B, Kuiper MA, Boerma EC: Central venous-arterial $\mathrm{pCO}(2)$ difference as a tool in resuscitation of septic patients. Intensive Care Med 2013, 39:1034-1039.

22. van Beest PA, Hofstra JJ, Schultz MJ, Boerma EC, Spronk PE, Kuiper MA: The incidence of low venous oxygen saturation on admission to the intensive care unit: a multi-center observational study in The Netherlands. Crit Care Med 2008, 12:R33.
23. Hernandez G, Pena H, Cornejo R, Rovegno M, Retamal J, Navarro JL, Aranguiz I, Castro R, Bruhn A: Impact of emergency intubation on central venous oxygen saturation in critically ill patients: a multicenter observational study. Crit Care Med 2009, 13:R63.

24. Levy MM, Fink MP, Marshall JC, Abraham E, Angus D, Cook D, Cohen J, Opal SM, Vincent JL, Ramsay G: SCCM/ESICM/ACCP/ATS/SIS international sepsis definitions conference. Crit Care Med 2001, 2003:1250-1256.

25. Dellinger RP, Levy MM, Carlet JM, Bion J, Parker MM, Jaeschke R, Reinhart K, Angus DC, Brun-Buisson C, Beale R, et al: Surviving sepsis campaign: international guidelines for management of severe sepsis and septic shock: 2008. Crit Care Med 2008, 36:296-327.

26. Vincent $J$, de Mendonca A, Cantraine F, Moreno R, Takala J, Suter PM, Sprung $\mathrm{CL}$, Colardyn F, Blecher S: Use of the SOFA score to assess the incidence of organ dysfunction/failure in intensive care units: results of a multicenter, prospective study. Working group on 'sepsis-related problems' of the European Society of Intensive Care Medicine. Crit Care Med 1998, 26:1793-1800.

27. Neviere R, Mathieu D, Chagnon JL, Lebleu N, Wattel F: The contrasting effects of dobutamine and dopamine on gastric mucosal perfusion in septic patients. Am J Respir Crit Care Med 1996, 154:1684-1688.

28. Elizalde Jl, Hernandez C, Llach J, Monton C, Bordas JM, Pique JM, Torres A: Gastric intramucosal acidosis in mechanically ventilated patients: role of mucosal blood flow. Crit Care Med 1998, 26:827-832.

29. Tugtekin IF, Radermacher $\mathrm{P}$, Theisen M, Matejovic M, Stehr A, Ploner F, Matura K, Ince C, Georgieff M, Trager K: Increased ileal-mucosal-arterial PCO2 gap is associated with impaired villus microcirculation in endotoxic pigs. Intensive Care Med 2001, 27:757-766.

30. Creteur J, De Backer D, Sakr Y, Koch M, Vincent JL: Sublingual capnometry tracks microcirculatory changes in septic patients. Intensive Care Med 2006, 32:516-523.

31. De Backer D: Lactic acidosis. Intensive Care Med 2003, 29:699-702.

32. Raza O, Schlichtig R: Metabolic component of intestinal PCO(2) during dysoxia. J Appl Physiol 2000, 89:2422-2429.

33. Jakob SM, Kosonen P, Ruokonen E, Parviainen I, Takala J: The Haldane effect - an alternative explanation for increasing gastric mucosal PCO2 gradients? Br J Anaesth 1999, 83:740-746.

34. Hurley R, Mythen MG: The Haldane effect - an explanation for increasing gastric mucosal PCO2 gradients? Br J Anaesth 2000, 85:167-169.

35. Schlichtig R, Bowles SA: Distinguishing between aerobic and anaerobic appearance of dissolved CO2 in intestine during low flow. J Appl Physiol 1994, 76:2443-2451.

doi:10.1186/cc13160

Cite this article as: Ospina-Tascón et al:: Persistently high venous-toarterial carbon dioxide differences during early resuscitation are associated with poor outcomes in septic shock. Critical Care 2013 17:R294.

\section{Submit your next manuscript to BioMed Central and take full advantage of:}

- Convenient online submission

- Thorough peer review

- No space constraints or color figure charges

- Immediate publication on acceptance

- Inclusion in PubMed, CAS, Scopus and Google Scholar

- Research which is freely available for redistribution 